$\xi=-1$

\title{
Fostering the Usage of Flipped Classroom: Student Engagement, Student Content Interaction and Student Motiva- tion
}

\author{
Yusrina Hayati Nik Muhammad Naziman1, Nadia Farleena Mohd Aznan1, Siti Maziah Ab Rahman1, Nor Haryanti \\ Md Nor1 Syukurriah Idrus2
}

123University Teknologi MARA,Campus Kelantan, 15150 Kota Bharu, Kelantan, Malaysia, 2University Teknologi MARA,Campus

Melaka, Malaysia

\begin{abstract}
Teaching and learning nowadays is different from past. Together with their environment where the students can easily have connected to internet and digital media make them ease to be technology savvy. Thus, flipped classroom become the option to the lecturer to change methods of teaching. However, there are lacked discussions in innovating teaching approach particularly in marketing. Hence, the objectives of this study to examine factors influencing the usage of flipped classroom and which factors contribute most to the usage of flipped classroom. The sampling of the data used is sample random sampling. The researcher will have used the structured questionnaire and divided into five sections including the demographic section. The study will analyze normality test, data cleaning, reliability test, descriptive and frequency analysis, Pearson correlation and Multiple Regression to test the hypothesis. Apparently, the expected result will be used to recommend in order having better understanding in student's learning particularly in using technology.
\end{abstract}

Keywords: Flipped Classroom; Blended Learning

\section{Introduction}

\section{Literature Review}

Online education becoming popularize since students can easily access the information through their fingertips. Government also urge to be in line with Industry 4.0 where the students should also be prepared with this revolution. Not to forgot that, the online activity is also not only for surfing but also technology in education can be build professional relationships through collaborating, coaching, and mentoring for social interactions in sharing ideas. In traditional classroom, students tend to be passive rather than active and traditional learning method tends to produce a low level of student's engagement and often pay less attention to the subjects they learn [1]. Looking at the perspective of the student itself, they are from the generation $Y$ which known as Echo Boomers or Millenniums that born with technology savvy. Thus the way they prefer to learn is using the Youtube, Videos Cable TV Channels, and also the Internet [2].

In recent years, education system require lecturer to engage more towards blended learning and also encourage student to learn more on self-learning time instead of traditional method of teaching and learning. Coping with mission and vision of organization which required lecturers to enhance their skilled with technology [3]. Looking back at the course outcomes of Digital Marketing; Demonstrate the ability and skills to use the digital technologies in delivering marketing mix towards online customer experience shows that it requires the lecturer to coop with the digital media to assist student in achieving the course outcomes. But somehow in this study the researcher would like to look from the perspective of the student how far this digital technology helps most in their learning process. As part of the course program require the student to complete the course with attending to the lecturer for 14 weeks with 3 hours in a week.

The flipped classroom is an approach to teaching and learning activities where students watch a video lesson outside the class through distance learning and have hands-on activities in the class. [4] Note that the flipped classroom or reverse classroom is an element of blended learning, integrating both face-to-face learning in the class through group discussion and distance learning outside the class by watching asynchronous video lessons and online collaboration. While, blended learning is simply defined as the activity of teaching and learning which combined face-to-face physical activities with online learning. Blended learning was practiced by mixed face-to-face and distance teaching and learning or the integration of both distance and face-to-face modalities to deliver instruction [5]. This could be slightly different with flipped classroom. Flipped classroom is also known as a student-center approach to learning where the students are more active than the instructor in the classroom activity. In this case, the instructor acts as a facilitator to motivate, guide, and give feedback on students' performance [6].

\section{The usage of flipped classroom.}

Recently, many researcher discussing about flipped classroom activities (online and face to face) are focused more on the production of videos for online use than on the interactive activities which are meant to build extra value in the classroom [13].

This technique become popularizes since Bergmann and Sams in 2012 introduced it [14]. Since then, there are a lots of software introduced and it is user friendly to be offer in the market which 
make the user like the lecturer easy to create and edited video. The students or Gen Y which easy to learn and study through YouTube.com which is easily to used and understand [15]. This researcher found that through videos, it will be effective in delivering the lessons. While the other researcher points out that good quality video lectures are rated higher by students than original videos created by teaching staff: this is a probable area for investment and more effective tagging and sharing of Open Educational Resources [16]

\subsection{Student motivation}

Motivation is an inner power that pushes humans to take an action or move toward a goal [8]. Students' motivation is defined as a spirit, initiative, and willingness of students to attend and learn material and in education, motivation is acknowledged as one of the most crucial elements which support students' performance and achievement [17].

According to self-determination theory, students' motivation is distinguished into two main types: intrinsic and extrinsic motivation [18]. Intrinsic motivation refers to those actions that individuals engage in as they are inherently interesting, fun, exciting, and enjoyable, while extrinsic motivation refers to individuals engaging in actions because they lead to reward or to avoid punishments [19]. This is more towards intrinsic motivation when it deals with flipped classroom. Likewise, further studied showed that the flipped classroom has promoted students' empowerment, development, and ability to learn independently or at their own pace [20].

The flipped classroom's success depends upon students undertaking substantial homework - and being encouraged to do by their own [21]. Many studies showed that the impact of applying the flipped classroom was to increase students' motivation in relation to learning activities. For example, [22] mentioned that students were able to learn based on simulated learning and that they were motivated to learn at their own pace; they also noted that the students wished to recommend the flipped classroom to their other friends.

The flipped classroom also increases self-perceived knowledge or self-efficacy in independent learning [23] and [24]. In terms of in independent learning, [25] also noted that students are able to work at their own pace in class. Therefore, it is to be likely that the implementation of the flipped classroom will be reasonable and needed to enhance their motivation.

\subsection{Student-content interaction.}

According to [26], three fundamental interactions should be established for successful teaching-learning with technology-based learning: student-content interaction, student-teacher interaction and student-student interaction. [27] Suggested student-interface interaction or interaction with technology tools as the fourth interaction to complete Moore's concept. All these interactions are very significant elements to apply in the flipped classroom approach in which technology is used as media to relearn and interact outside the classroom.

Students' interaction is the other positive impact in a flipped classroom environment either in the classroom or out of the campus learning system. Students' interaction refers to students' communication with all the elements in the learning environment including the instructor, students, and content [28]. It proves that students' social interaction in technology learning environment is more effective than that in traditional classroom without using technology; students in traditional classroom only interact physically in the classroom but not outside class hours [29]. It can be assumed that students' social interactions will increase when technology media is integrated in teaching-learning activities. Tech- nology use will indeed help students interact easily with all communities both inside and outside the class.

[30] Reported in his research that the students responded positively about flipping the classroom because the instruction helped them to collaborate with each other to solve problems. The flipped classroom enabled students to build a learning community and exchange ideas to solve problems [21]. Another reported that it could build the dialogue inside the class or virtually through distance learning outside the class hours [31].

[32] There are the different between traditional and flipped style learning which brought to come out with the students have a significant perception of the flipped learning approach. [33] Reported that the blending of new technology and the traditional classroom had established students' interactive learning, particularly outside the class through LMS. Another study mentioned that students can enrich the dialogue with their friends both inside and outside the class because the activity of teaching-learning in a flipped classroom is not just limited to behind the classroom wall [31]. Also, [34] reported that 75 students $(64 \%)$ in flipped learning class increased their interactions with the instructor and classmates.

\subsection{Students' Engagement.}

All researchers probably agree that the aim of flipped learning is to establish students' engagement with active learning. Students' engagement refers to students' active learning or students' desire to actively participate in routine class activity such as submitting homework, listening to the topic, working on what the instructor asks them to do, and actively attending the class [35]. Likewise, [36] mentioned that students' engagement resulted from students' motivation. The term students' engagement is frequently used for students' active learning or students' desire to actively participate in routine class activity such as submitting homework, listening to the topic, working on what the instructor asks to do, and actively attending the class [37].

Several studies showed that students had engaged in the flipped classroom. [21] Reported that students were able to prepare for inclass activities by watching and exploring on-line learning materials (e.g., online video lectures) before coming to class. Students felt confident when learning in the class because they had already prepared the lesson before coming to class. [38] Also reported that students could confidently produce a summary of the biological process in their own words by implementing the flipped classroom and they could be active in the class. Other researchers also mentioned students' confidence-by interacting with asynchronous video lectures outside the class, they could be more confident and prepared when participating in discussions in the class [21]. Students can enhance their engagement in classroom activity, participate in discussions, exchange ideas, and solve problems with their peers [31].

The use of the flipped classroom also promotes students' empowerment, development, engagement, and critical thinking. [34] Reported that the students engage the learning environment and engaged in the learning process. [20] Also reported that students participated and engaged in discussions in class, and they were confident in their ability to apply the knowledge. Additionally, [25] also noted that students enjoyed having the instructor available in class to help them while they worked on problems.

From all findings, it showed that the flipped classroom learning approach has been successfully practiced to better engage students in learning various subjects. In contrast, the class without flipping or traditional class tends to produce disengaged learning environment because this conventional learning model has some problems For example, teaching and learning activities only focus on text books and lectures, and students tend to be disengaged in active learning because they have a lack of time to express their abilities or performances in class. 


\section{Discussion related to the study.}

Most of the research paper agreed that flipped classroom can enhance learning process of the students which an educators wish to have active students rather than passive students. This could be brought into students' engagement. Students' engagement refers to students' actively participate in learning process like giving the attention to the subjects, do their homework, and free in giving ideas and opinion [20]. Likewise, [21] mentioned the impact of students' engagement leads to higher students' motivation.

Their research about students' engagement with the use of flipped classroom method. [23] Reported that when the student had the positive attitude towards the subjects due to the usage of video online, it will make them to prepare things required or asked by the lecturers ahead. Furthermore, Students felt confident and their understanding will be higher because they have prepared the materials earlier [24]. Other researchers also mentioned students' confidence also due to their own willingness to know and also to understand the subject who makes them wanted to participate with the discussion in the classroom [23] \& [25]. The study conducted by [26] reported that it is effective ways of teaching when the students were satisfied with the class meeting, they like to attend the class and also rather than boredom. [27] Reported that the students engage the learning environment and engaged in the learning process. Through flipped classroom, students can also create their learning community which helps them to exchange opinions and collaborate more [23]. Another reported stated that, this learning process is not stop only in the classroom but also continue at home enable students to ask further question and understand better [25].

\section{Methodology.}

Data collection was conducted through the questionnaire method. The questionnaire used both English and Malay so that it is flexible for the respondents to understand and answer the questionnaire given. Therefore, the questionnaire was distributed to gather the data and information related to the usage of video and Youtube in supporting their learning experience. The study basically uses traditional methods of teaching. But somehow, when the students get bored, the lecturer change the way of teaching to include video and also assignments to watch videos through Youtube. A twopart questionnaire is employed. The first part of this questionnaire tried to collect demographic background of respondents. Information including gender, age, level of income, the level of education, marital status, occupation and the frequency of using digital media in their learning experience. The second part of questionnaire asked about the constructs of study and ask respondent to show their level of agree and disagree to each question by using a 5-point Likert scale. The test of reliability shows how reliable the instruments being used is in order to measure the concepts and constructs of the research. Reliability of measurement indicates that how stable and consistent the instrument is in order to analyze the concepts and construct involved in the research, and shows the extent of which the measurement is free from error. Reliability test helps to examine the goodness of measures. In order to test the reliability of the instrument used in this study the popular method of applying Cronbach's Alpha is used. The Cronbach's Alpha value for dependent variable is 0.755 . The strength of association was considered as moderate which all the question of this section was positively correlated and acceptable. The Cronbach's Alpha value for independent variable (student's engagement) is 0.841 . The strength of association was considered as very good which all the question under this section was positively correlated and had been acceptable by respondents.

The Cronbach's Alpha value for independent variable (student's content interaction) was 0.784 . The strength of association was considered as good which all the question under this section was positively correlated and had been accepted by respondents. Next, the table above stated that there are five numbers of items for reliability analysis on student's motivation as independent variable. The Cronbach's Alpha value for independent variable (student's motivation) was 0.702 . The strength of association was considered as good which the entire question under this section is positively correlated and can be accepted by respondents.

Based on the regression analysis, the value of $\mathrm{R}$ squared was found to be $35.2 \%$. It means that only $35.2 \%$ of independent variables of flipped classroom can be explained by student motivation, student-content interaction and student engagement. Meanwhile, another $64.8 \%$ cannot be explained by the model. Therefore, the variables should be changed or added in the model in order to explain the dependent variable accurately.

On top of that, referring to the results from multiple linear regression, the hypotheses testing using SPSS software provided results in which the significant value of student's engagement and student's content interaction were 0.008 and 0.029 respectively. The values are less than $\mathrm{p}$-value of $0.05(\mathrm{p}<0.05)$. It shows that there is a significant relationship between student's engagement and student's content interaction towards the usage of flipped classroom. However, another variable which is student's motivation found to be not significant as it has p-value of 0.115 . Those value is more than $0.05(\mathrm{p}>0.05)$.

\section{Conclusion}

Based on the result gather, student's engagement and student's content interaction have a significant result which shows that it is factors influencing the usage of flipped classroom. And also based on the highest beta value, student's engagement show that it is the most influential factors for the usage of flipped classroom. Thus, the researcher can suggest that, by using the digital media in the other hand can also enhance the learning of the students. Particularly when the subject taught to the students were reading subjects and digital media helps to engage students with the lesson. Challenges for the lecturer is to equip with current needs of the students. Combining the blended learning and flipped classroom might be anew suggestion in a way to make students more understand and engage with the subjects.

\section{Acknowledgement.}

The authors would like to express their appreciation to Institute of Research Management and Innovation of MARA University of Technology (UiTM) ARAS 2016/2018 for funding the research.

\section{References}

[1] S. H. A. R. R. \&. Z. Z. Halili, "Enhancing collaborative learning in flipped classroom.," Australian Journal of Basic and Applied Sciences, p. 147-149. , 2014.

[2] L. Johnson, A. Becker, E. V. S. and A. \& Freeman, "NMC horizon report," The New Media Consortium, Higher Education Edition. Austin, Texas, 2014

[3] W. J. Schroer, "Generations X,Y, Z and the Others," Generations $\mathrm{X}, \mathrm{Y}, \mathrm{Z}$ and the Others, 2017.

[4] S. H. \&. Z. Z. Halili, " Flipping the classroom: What we know and what we don't.," The Online Journal of Distance Education and e Learning., pp. 28-35, 2015.

[5] S. B. Heilesen, "What is the academic efficacy of podcasting? Computers \& Education," pp. 1063-1068, 2010.

[6] A. \&. B. J. Sams, " Flip your classroom: Reach every student in every class every day.," International Society for Technology in Education (ISTE). , 2012

[7] Z. Z. a. S. H. Halili, "Flipped Classroom Research and Trends from Different Fields of Study," International Review of Research in Open and Distributed Learning, pp. 313-340, 2016.

[8] E. H.-J. C. \&. P. T. F. Harmon-Jones, "What is approach motiva- 
tion?," Emotion Review, pp. 1063-1068, 2013.

[9] S. Greener, "Flipped or Blended? What's the Difference and Does it Make a Difference to Learning in HE?," University of Brighton, Brighton, UK, 2017

[10] R. M. K. G. D. \&. K. S. P. Carini, "Student engagement and student learning: Testing the linkages.," Research in Higher Education, pp. 1-32, 2006.

[11] T. C. Nguyen, "Challenges of learning English in Australia towards students coming from selected Southeast Asian countries: Vietnam, Thailand and Indonesia.," International Education Studies, pp. 1320, 2010.

[12] S. O. E. P. J. W. C. M. H. D. H. D. .. W. M. P. Freeman, "Prescribed active learning increases performance in introductory biology.," CBE Life Sciences Education, pp. 132-139, 2007.

[13] Y. \&. H. A. D. Zhao, "Evaluating the flipped classroom in an undergraduate history course," HarvardX Research Memo , 2014.

[14] J. \&. S. A. Bergmann, " Flip your classroom: Reach every student in every class every day.," Washington, DC: Internal Society for Technology in Education. , 2012.

[15] D. Z. L. B. R. \&. N. J. Zhang, "Instructional video in e-learning: Assessing the impact of interactive video on learning effectiveness.," Information \& Management, pp. 15-27, 2006

[16] C. \&. S. N. Freeman-Herreid, "Case Studies and the Flipped Classroom.," Journal of College Science Teaching, pp. 62-66, 2013.

[17] M. S. F. H. S. \&. H. S. G. Cole, "Student learning motivation and psychological hardiness: Interactive effects on students' reactions to a management class.," Academy of Management Learning \& Education, pp. 64-85, 2004.

[18] L. \&. D. P. Abeysekera, "Motivation and cognitive load in the flipped classroom: Definition, rationale and a call for research.," Higher Education Research \& Development, pp. 1-14, 2014.

[19] E. L. \&. R. R. M. Deci, "Handbook of self-determination research," Rochester, NY: University of Rochester Press. , 2002.

[20] J. E. R. M. T. G. D. M. G. N. D. C. A. G. L. M. .. M. R. J McLaughlin, "The flipped classroom: A course redesign to foster learning and engagement in a health professions school.," Academic Medicine, pp. 236-243, 2014.

[21] M. K. K. S. M. K. O. \&. G. J. Kim, " The experience of three flipped classrooms in an urban university: An exploration of design principles.," The Internet and Higher Education, pp. 37-50, 2014.

[22] R. S. D. D. L. \&. B. N. Davies, " Flipping the classroom and in structional technology integration in a college-level information systems spreadsheet course," Educational Technology Research and Development, pp. 563-580, 2013.

[23] L. P. C. K. K. T. T. K. T. K. \&. F. E. Galway, "A novel integration of online and flipped classroom instructional models in public health higher education.," BMC Medical Education BMC Med Educ, p. 181, 2014.

[24] J. Enfield, " Looking at the Impact of the Flipped Classroom Model of Instruction on Undergraduate Multimedia Students at CSUN.," TechTrends TECHTRENDS TECH TRENDS, 2013.

[25] J. \&. X. F. McGivney-Burelle, "Flipping calculus," Primus, pp 477-486, 2013.

[26] M. Moore, " Three types of interaction," American Journal of Distance Education, pp. 1-6, 1989.

[27] D. C. W. D. J. \&. G. C. N. Hillman, " Learner-interface interaction in distance education: An extension of contemporary models and strategies for practitioners.," American Journal of Distance Education, pp. 30-42, 1994.

[28] Y. \&. R. T. C. Woo, " Meaningful interaction in web-based learning: A social constructivist interpretation.," The Internet and Higher Education, pp. 15-25, 2007.

[29] Z. J. Wang, "A new perspective of instructional interaction research in distance education: Structuralism.," Modern Distance Education Research, pp. 28-33, 2013.

[30] T. Roach, " Student perceptions toward flipped learning: New methods to increase interaction and active learning in economics.," International Review of Economics Education, pp. 74-84, 2014.

[31] J. E. G. L. M. E. D. A. D. C. A. G. D. M. R. M. T. .. \&. M. R. J. McLaughlin, " Pharmacy student engagement, performance, and perception in a flipped satellite classroom. Pharmacy student engagement, performance, and perception in a flipped satellite classroom.," American Journal of Pharmaceutical Education, pp. 1-8, 2013.

[32] B. H. A. G. N. \&. S. A. W. Love, " Student learning and perceptions in a flipped linear algebra course.," International Journal of Mathematical Education in Science and Technology, pp. 317-324, 2014.
[33] K. F. R. S. L. \&. G. K. Missildine, "Flipping the classroom to improve student performance and satisfaction.," Journal of Nursing Education, pp. 597-599, 2013.

[34] H. T. Hung, "Flipping the classroom for English language learners to foster active learning.," Computer Assisted Language Learning, pp. 81-96, 2015.

[35] S. C. \&. C. Y. Yang, " Technology-enhanced language learning: A case study.," Computers in Human Behavior, pp. 860-879, 2007.

[36] N. L. L. \&. B. P. Zepke, "Student motivation and engagement in learning.," In proceedings of the 32nd HERDSA annual conference, the student experience, Darwin, pp. 529-538, 2009.

[37] Ö. Delialioglu, "Student engagement in blended learning environments with lecture-based and problem-based instructional approaches.," Educational Technology \& Society, pp. 310-322, 2012.

[38] C. P. \&. S. S. Talley, "The enhanced flipped classroom: increasing academic performance with student-recorded lectures and practice testing in a "flipped" stem course.," The Journal of Negro Education, pp. 339-347, 2013. 